TI 2018-057/VI

Tinbergen Institute Discussion Paper
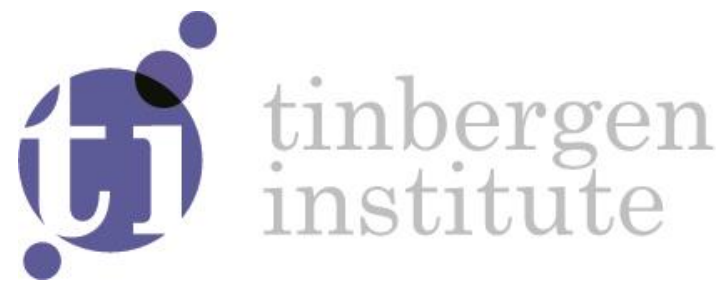

\title{
Cyclical and Stuctural Variation in Resource Reallocation: Evidence for Europe
}

Eric (E.J.) Bartelsman ${ }^{1}$

Paloma Lopez-Garcia ${ }^{2}$

Giorgio Presidente ${ }^{3}$

\footnotetext{
${ }^{1}$ VU Amsterdam

${ }^{2}$ ECB

${ }^{3}$ World Bank
} 
Tinbergen Institute is the graduate school and research institute in economics of Erasmus University Rotterdam, the University of Amsterdam and VU University Amsterdam.

Contact: discussionpapers@tinbergen.nl

More TI discussion papers can be downloaded at http://www.tinbergen.nl

Tinbergen Institute has two locations:

Tinbergen Institute Amsterdam

Gustav Mahlerplein 117

1082 MS Amsterdam

The Netherlands

Tel.: +31(0)205984580

Tinbergen Institute Rotterdam

Burg. Oudlaan 50

3062 PA Rotterdam

The Netherlands

Tel.: +31(0)10408 8900 


\title{
Cyclical and Stuctural Variation in Resource Reallocation: Evidence for Europe
}

\author{
Eric Bartelsman ${ }^{1}$, Paloma Lopez-Garcia ${ }^{2}$, and Giorgio Presidente ${ }^{3}$ \\ ${ }^{1}$ Vrije Universiteit Amsterdam; Tinbergen Institute; \\ ${ }^{2}$ ECB $;{ }^{3}$ World Bank
}

June 17, 2018

\begin{abstract}
This paper uses cross-country micro-aggregated data on firm dynamics and productivity from the ECB CompNet database to provide empirical evidence on factor reallocation in the EU. The analysis finds that reallocation is towards more productive firms although the magnitude varies across countries and over time. Variation in reallocation is related to structural differences in firm size distribution across countries as well as to variation in labor and product market institutions. Productivity enhancing reallocation generally rises in downturns but, similar to findings for the US, it did not pick up in the great recession. The sharp drop in exports and tightness in credit markets are seen to provide a partial explanation for this lack of a silver lining.
\end{abstract}

Keywords: Great Recession, Factor Reallocation 


\section{Introduction}

With the onset of the financial crisis far behind us, the recovery only recently is gaining traction in Europe. Much uncertainty remains about the path ahead, with different scenarios available for growth, employment, investment, productivity and potential GDP. In this paper, we position the macro takeoff point by exploring the micro-level detail of resource reallocation between firms and its effect on growth. In particular, we explore whether the sharp drop in activity at the outset of the crisis, and the lengthy period of low activity and distressed financial markets has affected the patterns of reallocation of resources, both employment and capital, across producers.

The paper also explores whether differences in policy environment and economic structure across the EU countries generates different patterns of resource reallocation. These differences likely can lead to differing responses to macroeconomic shocks. The differences also could affect growth patterns across countries going forward. In this paper, we document the patterns of resource reallocation in different countries and industries in the EU. While such analysis is available for the U.S. and a few EU countries, we provide the first comprehensive account for a sample of EU countries. We present evidence on whether productivity enhancing reallocation (PER) is observed, that is whether resource move towards more productive firms. In particular we assess whether these patterns vary systematically across countries, whether they changed over the cycle, and in particular what happened during the Great Recession and the ensuing European sovereign debt crisis. We assess whether these differences are related to the nature of the shocks or to the characteristics of labor markets, financial markets, and output markets.

This paper complements the work by Foster, Grim, and Haltiwanger (2016) on reallocation in the United States. As in that paper, the main focus of this paper is on reallocation and the possible 'cleansing' effect of the great recession. What are the cyclical patterns of reallocation and to what extent have resources moved away from less productive and towards more productive firms over the course of the crisis? Owing to the shorter timespan of firm-level data in Europe, we are unable to explore whether the effects seen in the current crisis differ from those in previous major downturns, as was done for the U.S. We can go beyond the analysis done for the US because there is considerable variation in the data over several country-sector-specific cycles. Further, in addition to the analysis of Foster, Grim, and Haltiwanger (2016) on labor reallocation, we analyze capital reallocation because the necessary data is available in the EU. In our paper we explore patterns of labor and capital reallocation through variation across EU countries in economic structure, labor and product market regulations, financial development and international exposure.

While we conduct comparable excercises, our paper differs in some important ways from the work of Foster, Grim, and Haltiwanger (2016). Our work is based on a 'micro aggregated' database of cross country and industry information drawn from firm-level datasets from a selection of countries (Lopez-Garcia and di Mauro 2015) and uses country and industry specific downstream activity indicators to control for demand shocks. By contrast, Foster, Grim, and Haltiwanger use firm-level data and state-level economic conditions to control for demand shocks. Conducting the analysis at the firm-level in a particular country allows more flexibility in the empirical specifications, but would preclude controlling for country specific circumstances and make identification of the effects of changes in policy environment very difficult. More importantly, because the data sources in each EU country are confidential, they cannot be analysed jointly. Instead, our cross-country panel dataset contains a set of observations within each country, industry and year that are representative of a group firms, collected in such a manner that they are not disclosive of individual firms and thus can be combined for cross-country analysis ${ }^{1}$

\footnotetext{
${ }^{1}$ The underlying methodology of distributed micro data analysis is described in Bartelsman, Hagsten, and
} 
In the past decades, much evidence has been collected, for the US, EU and developing countries on resource reallocation. Even in non-crisis periods, and for industries that are neither growing nor shrinking, a continuous process of job creation, job destruction and of firm entry and exit takes place (e.g. Davis and Haltiwanger, (1992); Bartelsman, Scarpetta, and Schivardi, (2005); Ayyagari, Demirgüç-Kunt, and Maksimovic, 2011). Models to explain such reallocation are based on frictions or distortions that prevent instantaneous optimality of resource allocations. These frictions could result from labor search, product market search, financial frictions, entrepreneurial barriers, or many other causes (Jovanovic, 1982; Mortenson and Pissarides, 1994; Hopenhayn, 1992; Cooley and Quadrini, 2001; Cooper and Halitwanger, 2006; Hsieh and Klenow, 2009; Bartelsman, Haltiwanger, and Scarpetta, 2013). The effects of reallocation in the EU have been discused in recent papers (e.g. Bartelsman, Haltiwanger, and Scarpetta, 2013; Andrews and Cingano, 2014), but to our knowledge we are the first to explore how the cleansing effect in a recession may depend on the economic and policy environment, on credit conditions or on trade.

Much of the early literature on reallocation concerned employment. The gross job flows of Davis and Haltiwanger (1994), could result from employment changes at continuing firms or through firm entry and exit. Since then, a parallel literature has grown on capital input reallocation, with firm level decisions on investment or retirements of capital. Generally, less comprehensive data is available for capital than is needed to mimic the methods of studying labor reallocation. In particular, retirements, economic obsolescence, or sale of used capital is not collected systematically by statistical agencies to the same extent as flows in the labor market. Nonetheless, business surveys often have enough information on asset values and accumulation to conduct some interesting analysis (e.g. Cooper and Haltiwanger, 2006). For the recent recession, with a severe financial crisis, understanding the interaction between reallocation of capital and the problems in the financial markets is important enough to develop methods that can make use of the limited data. For that reason, this paper uses balance sheet information on real fixed assets, an imperfect approximation of the real stock of capital, to be able to analyse cross-country differences and cyclical properties of both employment and capital reallocation.

The resource allocation process can serve to enhance aggregate productivity, by shifting resources from less to more productive firms, or by having cohorts of entering firms that are more productive than exiting firms. In general, in well functioning economies, resource allocation is productivity enhancing, but that is not always the case. A recent literature explores market distortions that can affect reallocation (Hsieh and Klenow, 2009; Restuccia and Rogerson, 2008; Bartelsman, Haltiwanger, and Scarpetta, 2013; Gopinath and others, 2017). Systematic evidence is being collected to compare such reallocation across countries and over time, often supported by multinational organisations such as the OECD ${ }^{2}$ Eurostat ${ }^{3}$ and in the CompNet project of the $\mathrm{ECB}{ }^{4}$

When resource allocation patterns during a downturn are productivity enhancing, this is referred to as the cleansing effect which provides a silver lining to economically painful periods (Caballero and Hammour 1994). Different theoretical mechanisms exist which would promote or reduce the cleansing effect. Below, we will provide an overview of the theories that provide context for our empirical results. In all the theories, some underlying mechanism is present that prevents resources from being allocated to their best use at each instant, otherwise there would be no potential cleansing. The interesting research questions are to find out which of the mechanisms are innate to informational and technical frictions and which relate to policy

\footnotetext{
Polder (2018).

${ }^{2}$ Criscuolo, Gal, and Menon (2014).

${ }^{3}$ Bartelsman, Hagsten, and Polder (2018).

${ }^{4}$ Lopez-Garcia and di Mauro (2015).
} 
induced distortions. Similarly, it may be of interest to find out which of the frictions or which components of costs and benefits of reallocation change over time and over cyclical episodes.

Besides frictions of some type, PER requires dispersion in productivity. Such dispersion is a feature in early models of heterogeneous producers, such as Lucas $(1978,1988)$ and Hopenhayn (1992). In these models, entrants receive a draw from a productivity distribution, and/or they receive idiosyncratic productivity shocks in each period. Frictions and distortions may prevent firms from instantaneously reaching their optimal scale where marginal products of inputs equal their marginal cost, although the direction of movement of resources should be from low to high marginal benefits.

The strength of PER will depend on the benefits of moving towards optimal size and the costs of achieving this. Larger shocks can increase potential benefits, as can a steeper relationship between profit and deviation from optimal size. The costs can depend on adjustment frictions and policy-induced distortions, but also on available supply of productive inputs. A rich literature exists on exploring the effects of employment protection on reallocation (e.g. Bertola and Rogerson, 1997; Bassanini, Nunziata, and Venn, 2009; Hagedoorn and Manovskii, 2008; Poschke 2009; Bartelsman, Gatier, and de Wind, 2016). Also, costs of vacancy creation or costs of starting a new business can change the calculus of reallocation. A related literature exists on financing costs and reallocation of capital. In heterogeneous firm models, frictions in capital arising from asymmetric information, can result in allocations of capital that may not equate marginal costs and benefits (see e.g. Bernanke, Gertler, and Gilchrist. 1996; Cooley and Quadrini 2001; Midrigan and Xu, 2014; Buera and Moll 2015;)

Each of these cost and benefits components can be subject to trends, for example owing to changes in technology, but can also differ across countries, for example through differences in policy stance. In the U.S., evidence is building up that the magnitude of job reallocation is declining secularly (Hyatt and Spletzer, 2014; Decker et al., 2015), although no clear answer is available about the causes of the decline. By contrast, evidence in Bartelsman, Gautier, and de Wind (2016), shows that in the EU reallocation seems to be higher among innovative and ICT intensive firms, likely because the magnitude of the shocks facing these firms is larger.

Reallocation and productivity enhancing reallocation also may differ over the cycle, as the nature of the shocks change and as the relationship between benefits and costs are altered. Foster, Grim, and Haltiwanger (2016) review many of the arguments about cylicality of reallocation, with as a general finding that it is less costly in downturns, although some distortions may make it more costly. The exact nature of the cyclical changes depend on the factor, labor or capital, but can also differ across recessions, owing to the underlying causes and magnitudes of the shocks. Another issue is whether the costs are associated with changes at continuing firms, or through entry and exit margins. Often through these margins 'scarring' can generate long lasting effects of recessions.

For labor inputs, reduced tightness in the labor market during downturns should reduce search frictions. Krussel and others (2017) present a model of the cyclical properties of gross worker flows, within the search tradition. Policy may also change the incentives for firms to shed workers during downturns. Boeri and Bruecker (2011) study the effects of short term work programs and find that they reduce job losses at the onset of the crisis. They further point out that effects may be asymmetric, causing more harm in upturns and that exact effects depend on interactions with other labor market institutions related to employment protection and wage bargaining regimes.

For capital inputs, the effect of the cycle on costs and benefits of reallocation is less clear cut. In empirical research using data on US firms from the Compustat database, Eisfeldt and Rampini (2005) find that the amount of capital reallocation between firms is procyclical. They find this surprising because they argue that the benefits for reallocation are counter cyclical 
because the dispersion of marginal capital productivity is higher in recessions. While benefits of reallocation may be higher, costs for attracting capital in a downturn could also be higher. Consistant with this, Lee and Mukoyama 2008, find that firm entry is more procyclical than exit. The higher costs of capital reallocation may also lead to scarring, such that the negative productivity effects of a downturn can be felt long after the recession is over, as found by Beura and Moll (2015).

The next section will describe the CompNet data and provide some summary statistics. Following this, we provide a baseline estimate of productivity enhancing reallocation. The baseline is expanded by looking at PER across countries and by firm size. We present evidence on how the cleansing is affected by product market competition and labor market regulation. Next we assess the cyclical nature of PER and explore how it varies over the cycle and in particular during the Great Recession and the European sovereign debt crisis. We conclude with thoughts on further work needed to understand how structural policies can affect long-run growth through reallocation.

\section{$2 \quad$ Data and descriptive statistics}

\subsection{The CompNet dataset}

A detailed description of the CompNet micro-based database that encompasses a very wide set of indicators related to productivity and competitiveness can be found in Lopez-Garcia and di Mauro (2015) ${ }^{5}$ The document contains a general description of the construction of the database and the methods applied to clean and process the data in a harmonized fashion. The paper also provides detailed information on country-specific coverage, sample representativeness and data characteristics. The underlying firm-level data sources are varied although most countries rely on administrative data (firm registries) and a few on surveys carried out by the national central banks. Despite the heterogeneity in terms of sources, target populations are defined in the same way across countries, aiming at private sector, non-financial corporations with employees consistent with the definition of institutional sector S11 in the European System of Accounts (that is, private non-financial enterprises excluding sole proprietors).

For our study, we have made a selection of six of the fourteen countries available in the 4th vintage of the CompNet database that have good coverage of large as well as of small firms (less than 20 employees). Our selection further is predicated on availability of all indicators needed for this paper for the full sample period, 2001-2012. Our sample includes northern EU countries Belgium and Finland, southern countries Spain and Italy, and accession countries Slovenia and Estonia. Table 1 below provides an overview of the coverage and characteristics for the countries used in this research.

The first column of table 1 shows the coverage of the total economy, comparing the aggregate of the CompNet data to aggregate employment of the National Accounts. Columns 2 to 5 show the coverage in terms of number of firms (legal firms with employees, operating in the same sectors as in CompNet) by size class, of the CompNet data vis-à-vis Eurostat Structural Business Statistics. The last column shows the employment coverage of micro-firms in CompNet, that is, of firms with less than 10 employees. As seen in the table, coverage of total employment as well as of firms belonging to different size classes, particularly of micro-firms, is quite good.

The dependent variables used in this paper, namely employment growth and real capital growth, have been collected through the CompNet's "labour" module. The data have been

\footnotetext{
${ }^{5}$ Researchers can apply for access to the most recent version of the CompNet data at https://www. comp-net. org/data/.
} 
Table 1: CompNet Data Coverage (pct)

\begin{tabular}{lcccccc}
\hline & $\begin{array}{c}\text { Coverage of } \\
\text { employment in } \\
\text { National Accounts } \\
\text { (Eurostat) }\end{array}$ & \multicolumn{4}{c}{$\begin{array}{c}\text { Coverage of population } \\
\text { of firms by size class }\end{array}$} & $\begin{array}{c}\text { Coverage of } \\
\text { employment } \\
\text { micro-firms }\end{array}$ \\
Country & $20-49$ & $50-249$ & $250+$ & & \\
\hline Belgium & 39 & 66 & 79 & 86 & 91 & 70 \\
Estonia & 56 & 90 & 88 & 95 & 86 & 87 \\
Finland & 45 & 75 & 80 & 84 & 92 & 79 \\
Italy & 30 & 26 & 76 & 87 & 89 & 39 \\
Slovenia & 46 & 49 & 85 & 91 & 97 & 53 \\
Spain & 32 & 35 & 59 & 54 & 54 & 41 \\
Sources: Eurostat National Accounts and Structural Business Statistics Notes: Coverage relative to National Accounts refer to 2005. \\
Coverage relative to the population of firms with at least 1 employee operating in the sectors covered by CompNet. It refers to 2010. \\
CompNet covers all sectors of the non-finanical busness economy excluding manufacturing of refine petroleum and utilities. Sector 12 \\
(Manufacturing of Tobacco) is missign in Estonia, Finland and Slovenia.
\end{tabular}

cross-checked with other sources, and the module has been documented in Fernandez and others (2016). The main objective of the labour module is to provide cross-country comparable indicators of firm growth. The labour module considers growth from $t-3$ to $t$ for 3 -year moving windows starting in 2001 through 2012. This setup restricts the analysis to firms that continue in the sample between $t-3$ and $t$, i.e. we only see growth at surviving firms, or the intensive margin.

Firm growth (in either labor or real capital) will be understood in the remaining of the paper as average annual growth in terms of employees (or real capital stock) of a 'representative firm' within a particular country/macro-sector/year. For each country/macro-sector/year, firms are classified in 25 groups, depending on their size-class transition from a particular size quintile in period $t-3$ to a quintile in period t. For each cell in the transition matrix, the median size of the firms in that cell, their median real fixed assets as well as their median productivity and several financial ratios in the initial period $t-3$ are known. In our baseline data we compute the employment (or capital) growth for each cell over the three year window by using the median initial size or stock of fixed assets in the cell and the median firm size (or real fixed assets) of all firms in the corresponding size quintile in time $t{ }^{6}$ In the appendix table A1, we compare results of our baseline regressions of productivity enhancing reallocation using our computed growth measures with the actual growth of continuers that are available only for a subset of our data referring mostly to the pre-crisis period. The overall coefficient for productivity enhancing reallocation is quite similar, as are the patterns across countries. Further, the correlation between the two measures across all observations is $80 \%$, and the variation across the cells of the transition matrix is similar as well as shown in Figure A1 in the appendix.

The interpretation of our dependent variable is the annual growth rate of factor input for a 'representative' firm proxying all the firms in that cell in the transition matrix. Notice that even if the representative firm stays in the same category, we could get a growth rate different from zero, because the median size in a given quintile can change within a three years window. To account for differences in the probability of firms to be in a particular cell of the transition matrix, we use total employment in each cell to construct weights to be used in weighted regression, reflecting how likely it is, for example, to observe firms belonging to the lowest quintile to move in three years in the highest one.

\footnotetext{
${ }^{6}$ We compute growth rates such that the median firm-size by quintile in $t$ reflects that of the full sample of firms, not just of continuers.
} 
The database used for this paper features several advantages over previously used sources. First, firm growth is computed in the same manner across all countries for 8 macro-sectors (corresponding roughly to the 1-digit NACE industries, see Appendix tables A2 for more information), in our sample over the period 2001-2012, which allows us to use panel data techniques to control for country, sector, and time specific characteristics. Second, we have a rich set of information on other characteristics of each type of firms, either defined in average levels or growth over the 3-year windows, or for the initial period in each window. This allows for dynamic specification in our regressions.

Table 2 shows the average annual employment growth rates computed as $100\left(\left(x_{t} / x_{t-3}\right)^{\frac{1}{3}}-1\right)$ from a quintile in period $t-3$ (row) to a quintile in period $t$ (column) on average across countries, industries and rolling windows. In the Appendix, Table A3 shows the growth rates for real capital.

Table 2: Average Employment growth (pct) in transition matrix cells.*

\begin{tabular}{lrrrrr}
\hline & $\mathrm{Q}_{t}$ & $\mathrm{Q}_{t}$ & $\mathrm{Q}_{t}$ & $\mathrm{Q}_{t}$ & $\mathrm{Q}_{t}$ \\
\hline $\mathrm{Q} 1_{t-3}$ & 6 & 24 & 49 & 78 & 122 \\
$\mathrm{Q} 2_{t-3}$ & -20 & 0 & 16 & 45 & 101 \\
$\mathrm{Q} 3_{t-3}$ & -32 & -14 & -1 & 17 & 77 \\
$\mathrm{Q} 4_{t-3}$ & -45 & -31 & -16 & -2 & 40 \\
$\mathrm{Q} 5_{t-3}$ & -52 & -46 & -36 & -20 & 0 \\
\hline${ }^{*} \mathrm{Q} 1$ is the quintile of smallest firms, & Q5 the largest.
\end{tabular}

For the purpose of this paper, we will define "job creation" as employment growth in the transition matrix cells with positive employment growth relative to total employment in the relevant country/macro-sector/year. Job destruction is measured as the employment change in shrinking transition matrix cells relative to industry employment.7 Because of the method by which we construct employment growth of the representative firm, and our measures of job creation and destruction, we cannot exactly compare our results to other studies although the patterns of job flows match evidence from other sources, such as DynEmp, over the cycle.

Table 3 provides summary statistics for the 'representative' firms that have negative employment growth versus those with positive employment growth. To reiterate, a 'representative firm' portrays the median of the underlying firms that fall in a transition matrix cell, so in this table we compare those firms falling in a cell with positive employment growth vs those in cells with negative growth. On average TFP is higher (lower) than the sector average for positive (negative) growth firms. Labor productivity also is higher. While growing firms are smaller, both in terms of labor and capital, they do have much higher capital intensity and low average capital productivity. In later analysis, where we control for industry and size fixed effects, we can parse out how employment growth relates to initial period characteristics.

There are some caveats attached to the dataset we use for our analysis, although summary statistics below show that our indicators are capturing the features we would like to measure. To start, we are not able to cleanly separate the effects of firm entry and exit from changes at continuing firms. In many of the countries the firm-level source data are not based upon registers that control well for exit, mergers, and other changes that distinguish new firms from continuing firms. Instead, we use rolling windows of firms that continue for three years to define the transition matrix. While the rolling windows by construction only consider continuing firms, our method of computing employment growth for cells in the transition matrix, ensures that

\footnotetext{
${ }^{7}$ An alternative measure of job creation and destruction ignores the cells in the diagonal of the transition matrix.
} 
Table 3: Summary statistics for growing and shrinking firms

\begin{tabular}{lrr}
\hline & $\begin{array}{r}\text { Firms with negative } \\
\text { employment growth }\end{array}$ & $\begin{array}{r}\text { Firms with positive } \\
\text { employment growth }\end{array}$ \\
\hline Average employment growth rate & -0.23 & 0.36 \\
Ratio TFP to sector average & 0.94 & 1.04 \\
Productivity of labor (in ,000s) & 32 & 41 \\
Real value added (in ,000s) & 43251 & 40418 \\
Employment & 8.40 & 4.74 \\
Real capital stock (in ,000s) & 79 & 67 \\
Investment ratio (Change of capital over lagged capital stock) & 0.16 & 0.17 \\
Wages (in ,000s) & 22 & 22 \\
Implicit interest rate & 0.05 & 0.05 \\
Capital intensity (,000s of euros per employee) & 0.36 & 0.36 \\
Profit margin (Operating surplus over turnover) & 0.03 & 0.05 \\
Prob. of being credit constrained & 0.11 & 0.09 \\
Cash holdings (Cash over total assets) & 0.09 & 0.11 \\
Collateral (share of fixed tangible assets) & 0.27 & 0.28 \\
Debt burden (interests over profits) & 0.12 & 0.08 \\
Equity debt ratio & 0.78 & 0.80 \\
\hline
\end{tabular}

total employment by quintile in both year $t$ and $t-3$ match that of the cross sections of all firms.

Summarizing, the data used in the empirical exercises are available for 6 countries, 8 macrosectors (1 digit sector at the NACE rev.2 classification system), 12 years (2001-2012) and 25 'representative firms' or transition cells. The first growth rate window is for 2004 relative to 2001 and the last one is 2012 relative to 2009. Hence we have a maximum panel size of 6 countries*8 macro-sectors*9 years*25 cells. All cell ('firm') characteristics, like size or productivity, are computed at time $t-3$, that is before the growing or shrinking episode takes place. we have considered several possibilities to flag the Great Recession. We analyse the initial downturn and the subsequent European sovereign debt crises separately, with a dummy for the great recession (GR) taking a value one for the window ending in 2009 and a dummy for the sovereign debt crisis (SDC) taking the value one for the windows ending in 2011 and 2012.

Table 4: Correlation of dependent variable with main regressors

\begin{tabular}{|c|c|c|}
\hline & $\begin{array}{c}\text { Employment Growth } \\
\Delta \mathrm{L}\end{array}$ & $\begin{array}{c}\text { Real Capital Growth } \\
\Delta \mathrm{K}\end{array}$ \\
\hline Employment growth & 1 & 0.849 \\
\hline Real capital growth & 0.849 & 1 \\
\hline Growth in downstream activity & 0.034 & 0.088 \\
\hline Log (relative firm TFP) & 0.230 & 0.172 \\
\hline Initial firm size & -0.434 & -0.309 \\
\hline
\end{tabular}

Table 4 provides correlations in the dataset between the two dependent variables used in our exercises, namely employment and real capital growth, and the regressors. As seen, growth correlates positively with our proxy for the cycle, namely growth in real activity of downstream sectors. It also correlates positively with $(\log )$ initial relative firm productivity and, negatively, with size. 


\section{$2.2 \quad$ Proxy for Cyclical Shocks}

To tackle the endogeneity of the cycle, we construct a proxy variable to capture exogenous demand variation. The proxy for the cycle is generated using methodology first developed by Shea (1993) and applied in Bartelsman, Caballero, and Lyons (1994). For each producing sector in each country (the upstream sector), a weighted average is calculated of real production (or expenditure) in domestic and foreign downstream industries (or final demand categories). For each of the upstream sectors, the shipments of output to domestic downstream sectors and final demand as well as shipments to foreign downstream sectors and foreign final demand are used as weights. Data for these downstream shipments are recorded in the World Input Output Tables (Timmer and others 2015), and are available through 2011. The 2012 values are extrapolated from 2011.

Following the Shea method, we ensure exogeneity of the cyclical proxy. A downstream industry is excluded from the analysis if that industry itself contributes significantly to the input use of the upstream sector, thereby ensuring exogeneity. In our application, we exclude the downstream sector if it contributes more than 1 percent of the material input of the upstream sector. Exluding these, we use all remaining domestic and foreign downstream industries and final demand categories for which real production or expenditure data are available. We first match real final demand expenditures for all countries available in the OECD 'Annual National Accounts' database. Next, for downstream industries we map country/sector information from the 2016 version of the OECD STAN database to matched country/sector columns of the WIOD. Finally, real country/industry sales from the CompNet data itself are used to match to any remaining unmatched columns of the WIOD. The mapped shipments columns from the WIOD dataset are converted to shipment shares that sum to unity for each upstream industry. For all upstream sectors, downstream sector convering at least 80 percent of total shipments have been mapped, ensuring the 'relevance' of the weighted downstream activity indicator in the terminology of Shea. The resulting weighted index of downstream activity (production or expenditures) is converted to a three year moving window growth rate to match the dependent variables in our analysis. This consitutes the independant variable for the cyclical shock, labelled $\Delta$ cycle in the regression tables.

\section{Productivity Enhancing Reallocation: Structural Issues}

In the first stage of the analysis we explore whether reallocation is productivity enhancing in our sample of European countries, that is, whether firms that are less productive than other firms in their sector tend to shrink while productive firms expand. Following Foster, Grim, and Haltiwanger (2016) we estimate the following equation using our 'representative firm' data to explore productivity enhancing reallocation:

$$
\Delta x_{i, c, s, t}=\beta_{1} \Delta \text { cycle }_{c, s, t}+\beta_{2} \operatorname{Rel}_{.} \operatorname{prod}_{i, c, s, t-3}+\beta_{3} \operatorname{Size}_{i, c, s, t-3}+\gamma \mathrm{FE}+\varepsilon_{i, c, s, t}
$$

where the operator $\Delta$ gives the annual average growth rate of a variable in time $t$ relative to year $t-3, x$ represents either employment $L$ or a measure of real capital $K$, the cycle is proxied by an indicator of growth in exogenous downstream activities, "Rel. prod" is initial productivity $(\log$ TFP) of the representative firm in period $t-3$ relative to its industry average, Size refers to the initial size of the 'firm' (log of number of employees), FE are fixed effects, and $\varepsilon$ represents the error term. The subscript $i$ references our 'representative firm' namely one of the 25 cells in the 3-year employment size-quintile transition matrix, subscript $c$ is for country, $s$ for macro sector, and $t$ for time. TFP is estimated at the firm-level as the difference between firm's real value added and the predicted one according to technology coefficients estimated at the 2-digit 
industry level using a semi-parametric approach (e.g. Wooldridge 2009) to correct simultaneity bias. See Lopez-Garcia and do Mauro (2015) for more details.

Unless stated otherwise, each exercise includes the following fixed effects: i) country*macrosector*initial size quintile; ii) country*year, and iii) macro-sector*year. With this specification the analysis makes use of time variation within a given country/sector/size quintile controlling also for country and sector-specific shocks. To save space in the tables, we refer to the whole set of fixed effects simply as 'Controls'. Finally, all our regressions are weighted with total cell-level employment. This allows adjusting for the fact that the 'representative firms' of the transition matrix vary in size and that the number of firms in each cell varies as well 8

Table 5: Baseline Estimates of Productivity Enhancing Reallocation

\begin{tabular}{|c|c|c|}
\hline VARIABLES & $\begin{array}{c}(1) \\
\Delta \mathrm{L} \\
\end{array}$ & $\begin{array}{c}(2) \\
\Delta \mathrm{K} \\
\end{array}$ \\
\hline$\Delta$ cycle & $\begin{array}{c}0.0390 \\
(0.0304)\end{array}$ & $\begin{array}{c}0.185^{* * *} \\
(0.0465)\end{array}$ \\
\hline Rel. $\operatorname{prod}_{-3}$ & $\begin{array}{c}0.815^{* * *} \\
(0.0845)\end{array}$ & $\begin{array}{c}0.483^{* * *} \\
(0.0616)\end{array}$ \\
\hline Observations & 8,064 & 8,064 \\
\hline Adjusted R-squared & 0.489 & 0.503 \\
\hline Controls & YES & YES \\
\hline
\end{tabular}

Table 5 shows our baseline results for employment growth and for real capital growth. Conditional on the cyclical shock, growth in labor or capital for each 'representative firm' is positively correlated to its productivity (relative to all other firms in the industry) in the initial period. Similar to evidence for the US from Foster, Grim, and Haltiwanger (2016), there is significant productivity enhancing reallocation in our sample of EU countries.

The first question is whether the magnitude of productivity enhancing reallocation in the $\mathrm{EU}$ is similar to that in the US. An intuitive metric of comparison is the growth differential between firms one standard deviation above or below average productivity. This spread depends both on the magnitude of the coefficient $\beta_{2}$ and on the dispersion of productivity. This spread can be compared with the US, or can be compared across EU countries or over time. With the estimated parameter values of $\beta_{2}$ and the standard deviation of (log) TFP of approximately 0.22 , we see growth or shrinkage of $35 \%$ for labor and $21 \%$ for capital in the EU. The estimate for labor growth is much larger than for the US, but likely reflects the joint distribution of size and productivity and the variation of $\beta_{2}$ across size classes. A back of the envelope calculation reflecting these adjustments generates a spread that is more in line with results for the US as is discussed in the next sub-section.

The next exercises in this section analyze how productivity enhancing reallocation varies by firm characteristics or across countries and their policy or regulatory environment.

\footnotetext{
${ }^{8}$ On average across countries the four smaller quintiles of the size distribution refer to firms with less than 10 employees whereas the largest size quintile includes firms with average size around 20 employees and contains about $80 \%$ of employees.
} 


\subsection{Results by Firm Size}

Table 6 expands the baseline results by showing how the strength of PER varies by firm size in the initial period. The 25 representative firms are allocated to five groups based on initial size quintile and the parameter on initial productivity is allowed to vary for each of the five groups. Note that mean impact of initial size quintile already had been controlled for in the baseline using size quintile fixed effects. On average, the $\beta$ coefficient remains significantly positive for both labor and capital growth, but the smallest effect is found for firms in the largest initial size quintile.

Table 6: Baseline by Initial Size (reference size class: first quantile of the size distribution); Employment and Capital

\begin{tabular}{|c|c|c|c|c|}
\hline VARIABLES & $\begin{array}{c}(1) \\
\Delta \mathrm{L}\end{array}$ & $\begin{array}{c}(2) \\
\Delta \mathrm{L}\end{array}$ & $\begin{array}{c}(3) \\
\Delta \mathrm{K}\end{array}$ & $\begin{array}{c}(4) \\
\Delta \mathrm{K}\end{array}$ \\
\hline$\Delta$ cycle & $\begin{array}{c}0.0390 \\
(0.0304)\end{array}$ & $\begin{array}{c}0.0600^{* *} \\
(0.0263)\end{array}$ & $\begin{array}{c}0.185^{* * *} \\
(0.0465)\end{array}$ & $\begin{array}{c}0.207^{* * *} \\
(0.0519)\end{array}$ \\
\hline Rel. $\operatorname{prod}_{-3}$ & $\begin{array}{c}0.815^{* * *} \\
(0.0845)\end{array}$ & $\begin{array}{c}0.693^{* * *} \\
(0.0974)\end{array}$ & $\begin{array}{c}0.483^{* * *} \\
(0.0616)\end{array}$ & $\begin{array}{c}0.272^{* * *} \\
(0.0473)\end{array}$ \\
\hline$\left(\mathrm{Q}_{t-3}==2\right)^{*}$ Rel. prod $_{-3}$ & & $\begin{array}{c}0.183^{* * *} \\
(0.0535)\end{array}$ & & $\begin{array}{c}0.158^{* * *} \\
(0.0478)\end{array}$ \\
\hline$\left(\mathrm{Q}_{t-3}==3\right) *$ Rel. prod $_{-3}$ & & $\begin{array}{c}0.131^{*} \\
(0.0710)\end{array}$ & & $\begin{array}{c}0.285^{* * *} \\
(0.0765)\end{array}$ \\
\hline$\left(\mathrm{Q}_{t-3}==4\right)^{*}$ Rel. prod $_{-3}$ & & $\begin{array}{c}0.321^{* * *} \\
(0.0820)\end{array}$ & & $\begin{array}{c}0.579^{* * *} \\
(0.0871)\end{array}$ \\
\hline$\left(\mathrm{Q}_{t-3}==5\right)^{*}$ Rel. prod $_{-3}$ & & $\begin{array}{c}-0.489^{* * *} \\
(0.0989)\end{array}$ & & $\begin{array}{r}-0.294^{* * *} \\
(0.0704)\end{array}$ \\
\hline Observations & 8,064 & 8,064 & 8,064 & 8,064 \\
\hline Adjusted R-squared & 0.489 & 0.503 & 0.503 & 0.528 \\
\hline Controls & YES & YES & YES & YES \\
\hline
\end{tabular}

Figure 1 displays the effect of lagged productivity on employment growth by initial size quintile. The figure shows the difference in employment growth for firms with initial productivity one standard deviation above the mean and below the mean. As seen, the effect is much smaller for the largest initial size class. The last bar shows the overall weighted average employment growth difference between high and low productive firms, which stands at about 17 percentage points. In the results for the US (Foster, Grim, and Haltiwanger 2016), which excludes the smallest firms, the weighted average was roughly 10 percentage points but dropped to 3 percentage points when only continuing firms were considered. The implication is that for young firms PER is much higher, which is consistant with our result of high PER for the smallest, and disproportionately youngest, firm size quintile.

\subsection{Results by Country: Regulation and Economic Conditions}

We start by showing that PER varies across countries. Table 7 shows the coefficient on lagged relative productivity for the growth of employment and real capital. Productivity enhancing 
Figure 1: Productivity Enhancing Reallocation by Size Class; Employment

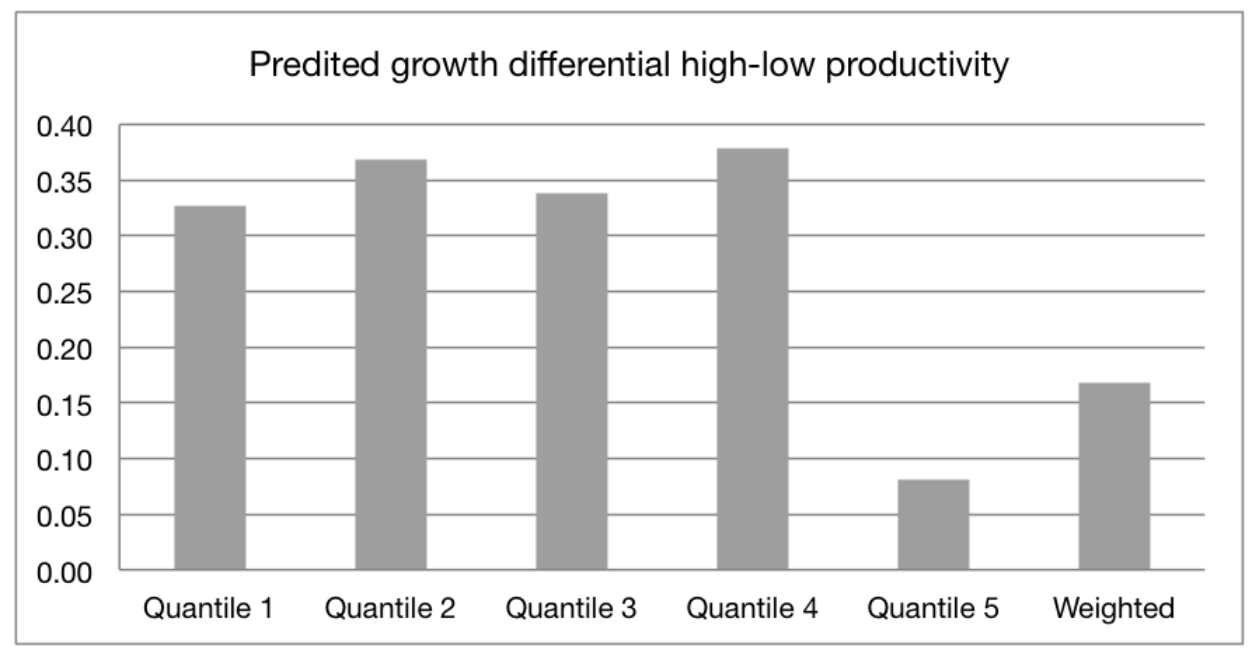

reallocation is significant in all countries, but the magnitude of the parameter varies, with smaller values in the accession countries. This opens up the question of what may be underlying the differences in the effect.

Is productivity enhancing reallocation affected by the regulatory environment in the country? We explore the effects of product market competition and labor market regulation on reallocation of labor and capital. The baseline regression is augmented to include a regulatory indicator and the interaction between the initial productivity and a regulatory indicator as shown in the following equation:

$$
\begin{gathered}
\Delta x_{i, c, s, t}=\beta_{1} \Delta \text { cycle }_{c, s, t}+\beta_{2} \text { Rel.prod }_{i, c, s, t-3}+\beta_{3} \text { Size }_{i, c, s, t-3} \\
+\beta_{4} \text { Rel.prod }_{i, c, s, t-3} \times \text { Regulation }_{i, c, s, t-3}+\beta_{5} \text { Regulation }_{i, c, s, t-3}+\gamma F E+\varepsilon_{i, c, s, t}
\end{gathered}
$$

Results from different regulatory indicators are shown in table 8 . Product market competition is captured by three concentration indicators, computed at the country/macro-sector/year level, available in CompNet: (1) Top10, the share of sector sales concentrated in the top 10 largest firms in the sector; (2) HH, the sector Herfindahl index; and (3) PCM, the weighted average price-cost margin, computed as turnover minus labour and intermediate costs over turnover. The raw regulatory indicators are converted into a boolean depending on whether the value is above or below the median of the raw indicator in each country in a given year, with a 1 denoting stringent regulation and a 0 more relaxed. We also include two country-aggregated indicators of product and labour market regulation, the PMR and the EPL, sourced from the OECD. In this case we interact the initial relative productivity of the firm with the level of the indicator and cluster the errors at the country level. The coefficient on the interaction with sector-specific indicators of product market competition, $\beta_{4}$, is significantly negative (at least at the $15 \%$ level) in all the shown specifications. The country-aggregate indicators are less so, with the exception of EPL in the employment growth regression. For example, when sales concentration in a given sector is larger than the median, the combined effect of productivity enhancing reallocation of labor is reduced from 1.05 to about 0.8 . 
Table 7: Baseline by Country (reference country: Belgium); Employment and Capital

\begin{tabular}{|c|c|c|}
\hline VARIABLES & $\begin{array}{l}(1) \\
\Delta \mathrm{L}\end{array}$ & $\begin{array}{c}(2) \\
\Delta \mathrm{K}\end{array}$ \\
\hline$\Delta$ cycle & $\begin{array}{c}0.0417 \\
(0.0291)\end{array}$ & $\begin{array}{r}0.187^{* * *} \\
(0.0455)\end{array}$ \\
\hline Rel. $\operatorname{prod}_{-3}$ & $\begin{array}{c}1.458^{* * *} \\
(0.107)\end{array}$ & $\begin{array}{r}0.502^{* * *} \\
(0.0629)\end{array}$ \\
\hline$($ country $==$ ESTONIA $) *$ Rel. $\operatorname{prod}_{-3}$ & $\begin{array}{c}-1.032^{* * *} \\
(0.108)\end{array}$ & $\begin{array}{c}-0.140 \\
(0.0978)\end{array}$ \\
\hline$($ country $==$ FINLAND $) *$ Rel. prod $_{-3}$ & $\begin{array}{r}-0.0806 \\
(0.174)\end{array}$ & $\begin{array}{c}0.0989 \\
(0.0916)\end{array}$ \\
\hline$(\text { country }==\text { ITALY })^{*}$ Rel. prod $_{-3}$ & $\begin{array}{l}-0.246 \\
(0.165)\end{array}$ & $\begin{array}{c}0.380^{* * *} \\
(0.118)\end{array}$ \\
\hline$($ country $==$ SLOVENIA $) *$ Rel. prod $_{-3}$ & $\begin{array}{c}-0.789^{* * *} \\
(0.124)\end{array}$ & $\begin{array}{l}-0.171 \\
(0.146)\end{array}$ \\
\hline$(\text { country }==\text { SPAIN })^{*}$ Rel. prod $_{-3}$ & $\begin{array}{c}-0.322^{* *} \\
(0.129)\end{array}$ & $\begin{array}{c}0.127 \\
(0.0932)\end{array}$ \\
\hline Observations & 8,064 & 8,064 \\
\hline Adjusted R-squared & 0.546 & 0.516 \\
\hline Controls & YES & YES \\
\hline
\end{tabular}

Robust standard errors in parentheses

*** $\mathrm{p}<0.01,{ }^{*} * \mathrm{p}<0.05, * \mathrm{p}<0.1$

Table 8: Regulation and Productivity Enhancing Reallocation

\begin{tabular}{|c|c|c|c|c|c|c|c|c|c|c|}
\hline VARIABLES & $\begin{array}{l}(1) \\
\Delta \mathrm{L}\end{array}$ & $\begin{array}{l}(2) \\
\Delta \mathrm{L}\end{array}$ & $\begin{array}{l}(3) \\
\Delta \mathrm{L}\end{array}$ & $\begin{array}{l}(4) \\
\Delta \mathrm{L}\end{array}$ & $\begin{array}{l}(5) \\
\Delta \mathrm{L}\end{array}$ & $\begin{array}{c}(6) \\
\Delta \mathrm{K}\end{array}$ & $\begin{array}{c}(7) \\
\Delta \mathrm{K}\end{array}$ & $\begin{array}{c}(8) \\
\Delta \mathrm{K}\end{array}$ & $\begin{array}{c}(9) \\
\Delta \mathrm{K}\end{array}$ & $\begin{array}{l}(10) \\
\Delta \mathrm{K}\end{array}$ \\
\hline Rel. $\operatorname{prod}_{-3}$ & $\begin{array}{c}1.052^{* * *} \\
(0.0976)\end{array}$ & $\begin{array}{c}1.033^{* * *} \\
(0.100)\end{array}$ & $\begin{array}{c}1.024^{* * *} \\
(0.0868)\end{array}$ & $\begin{array}{l}1.856^{*} \\
(0.833)\end{array}$ & $\begin{array}{c}2.863^{* * *} \\
(0.451)\end{array}$ & $\begin{array}{c}0.720^{* * *} \\
(0.0451)\end{array}$ & $\begin{array}{c}0.711^{* * *} \\
(0.0469)\end{array}$ & $\begin{array}{c}0.690^{* * *} \\
(0.0471)\end{array}$ & $\begin{array}{c}1.363^{* *} \\
(0.423)\end{array}$ & $\begin{array}{c}0.772 \\
(0.386)\end{array}$ \\
\hline Rel. $\operatorname{prod}_{-3} \times$ Top 10 & $\begin{array}{c}-0.231^{*} \\
(0.115)\end{array}$ & & & & & $\begin{array}{c}-0.174^{* *} \\
(0.0789)\end{array}$ & & & & \\
\hline Rel. $\operatorname{prod}_{-3} \times \mathrm{HH}$ & & $\begin{array}{l}-0.194 \\
(0.128)\end{array}$ & & & & & $\begin{array}{l}-0.157^{*} \\
(0.0899)\end{array}$ & & & \\
\hline Rel. $\operatorname{prod}_{-3} \times$ PCM & & & $\begin{array}{c}-0.210^{*} \\
(0.118)\end{array}$ & & & & & $\begin{array}{c}-0.135 \\
(0.0810)\end{array}$ & & \\
\hline Rel. $\operatorname{prod}_{-3} \times \mathrm{PMR}$ & & & & $\begin{array}{l}-0.394 \\
(0.475)\end{array}$ & & & & & $\begin{array}{l}-0.374 \\
(0.309)\end{array}$ & \\
\hline Rel. $\operatorname{prod}_{-3} \times \mathrm{EPL}$ & & & & & $\begin{array}{c}-0.658^{* *} \\
(0.212)\end{array}$ & & & & & $\begin{array}{l}0.00278 \\
(0.182)\end{array}$ \\
\hline Observations & 8,064 & 8,064 & 8,064 & 1,613 & 6,316 & 8,064 & 8,064 & 8,064 & 1,613 & 6,316 \\
\hline Adjusted R-squared & 0.475 & 0.472 & 0.474 & 0.513 & 0.535 & 0.475 & 0.474 & 0.473 & 0.444 & 0.422 \\
\hline Controls & YES & YES & YES & YES & YES & YES & YES & YES & YES & YES \\
\hline
\end{tabular}




\section{Productivity Enhancing Reallocation: Cyclical Issues}

In this section, we study patterns of reallocation over time. From a theoretical perspective, a deep recession could alter the calculus of costs and benefits to reallocation. If adjustment costs are convex, a sharp downturn likely will lead to less than expected reallocation, while concave adjustment costs will do the opposite. Further, there may be a relationship between the size of the cyclical shock and the productivity of the firm, for example if exports decline sharply and more productive firms are predominantly exporters, then PER may be reduced. Another possibility is that adjustment frictions themselves are related to productivity. For example, credit may be allocated on the basis of collateral that is unrelated to productivity of the firm. In this case, a tightening of credit may prevent PER, at least amongst firms most dependent on bank credit. Alternatively, it could be that credit constraints mostly affect low productive firms, in which case tightening overall credit conditions may not worsen PER. While generally PER is found to be countercyclical, the sharpness, depth and nature of the great recession and the European sovereign debt crisis may alter whether or not these episodes generated a silver lining from reallocation.

To address these issues, in Table 9 we regress employment growth and real capital growth on the cycle, on initial relative productivity, and their interaction for different periods separately: pre crisis for the windows ending in 2008 or before, the Great Recession (GR) for the window ending in 2009, and Sovereign Debt Crisis (SDC) for the windows 2008-2011 and 2009-2012. The interaction between initial relative productivity and the cycle captures whether PER is enhanced or muted over the cycle. Table 9 shows that for employment (columns 1-3) the interaction between cycle and initial productivity is negative in the pre crisis period, meaning that normal downturns enhance the PER of labour. However, the sign of the interaction becomes positive during the GR - indicating that over the Great Recession the downturn was less productivity enhancing. The cyclical pattern of cleansing returns to normal during the SDC. In short, our finding that downturns increase the productivity-enhancing reallocation of employment does not hold true for the Great Recession, when only the average extent of PER is in place at best.

As shown by columns 4 to 6 of Table 9 , results for capital reallocation are slightly different. While the sign of all the estimates are in the same direction as employment, PER shows statistically significant cyclical behaviour only in the SDC. Possibly, capital adjustment costs might hamper PER over the cycle, but due to tight credit conditions during the debt crisis, downturns might have been particularly effective at leading unproductive firms out of the market.

Figure 2 provides a graphical representation for the results by displaying the effect of lagged productivity on employment growth over the cycle in different periods. The figure quantifies the difference in employment growth for firms with initial productivity one standard deviation above and below the average. The first column shows that in the pre-crisis period, employment in the most productive firms grow 38\% more than their unproductive counterparts in normal times. The second column shows that in downturns, productive firms grow $40 \%$ more than the unproductive ones, suggesting that the cycle is "cleansing" away from less efficient producers ${ }^{9}$ However, the third column shows that during the Great Recession productivity differential are less important in explaining employment growth, as the difference between the most and least productive firms drops to $36 \%$. Finally, in the last column referring to the SDC the cycle reacquire its cleansing role, slightly outperforming the pre-crisis period.

Summarising, we find that downturns enhance the reallocation of employment towards the most productive firms in the pre-crisis period and during SDC, but less so during the GR. For capital, we find that downturns enhance PER only during the SDC.

\footnotetext{
${ }^{9}$ In the figure, a downturn is defined as a year-on-year decrease in sector real value added of $10 \%$.
} 
Table 9: Productivity Enhancing Reallocation over the Cycle

\begin{tabular}{lccc|ccc}
\hline & $(1)$ & $(2)$ & $(3)$ & $(4)$ & $(5)$ & $(6)$ \\
& & & & & & \\
& & & & & \\
& & & & \\
& & & & \\
VARIABLES & Pre-crisis & GR & SDC & Pre-crisis & GR & SDC \\
\hline & & & & & & \\
$\Delta$ cycle & $0.315^{* * *}$ & & -0.0461 & $0.398^{* * *}$ & & 0.133 \\
& $(0.0618)$ & & $(0.0536)$ & $(0.0825)$ & & $(0.124)$ \\
Rel. prod $_{-3}$ & $0.852^{* * *}$ & $1.034^{* * *}$ & $0.948^{* * *}$ & $0.446^{* * *}$ & $0.541^{* * *}$ & $0.526^{* * *}$ \\
& $(0.124)$ & $(0.116)$ & $(0.0907)$ & $(0.0852)$ & $(0.128)$ & $(0.0801)$ \\
Rel. prod $_{-3} \times \Delta$ cycle & $-0.599^{*}$ & $1.463^{* * *}$ & $-0.348^{* * *}$ & -0.0408 & 0.131 & $-0.382^{* *}$ \\
& $(0.355)$ & $(0.473)$ & $(0.0844)$ & $(0.272)$ & $(0.556)$ & $(0.173)$ \\
& & & & & & \\
Observations & 4,526 & 935 & 1,668 & 4,526 & 935 & 1,668 \\
Adjusted R-squared & 0.472 & 0.411 & 0.539 & 0.500 & 0.455 & 0.511 \\
Controls & YES & YES & YES & YES & YES & YES \\
\hline
\end{tabular}

Robust standard errors in parentheses *** $\mathrm{p}<0.01,{ }^{* *} \mathrm{p}<0.05,{ }^{*} \mathrm{p}<0.1$

Figure 2: Productivity Enhancing Reallocation over the Cycle (Employment)

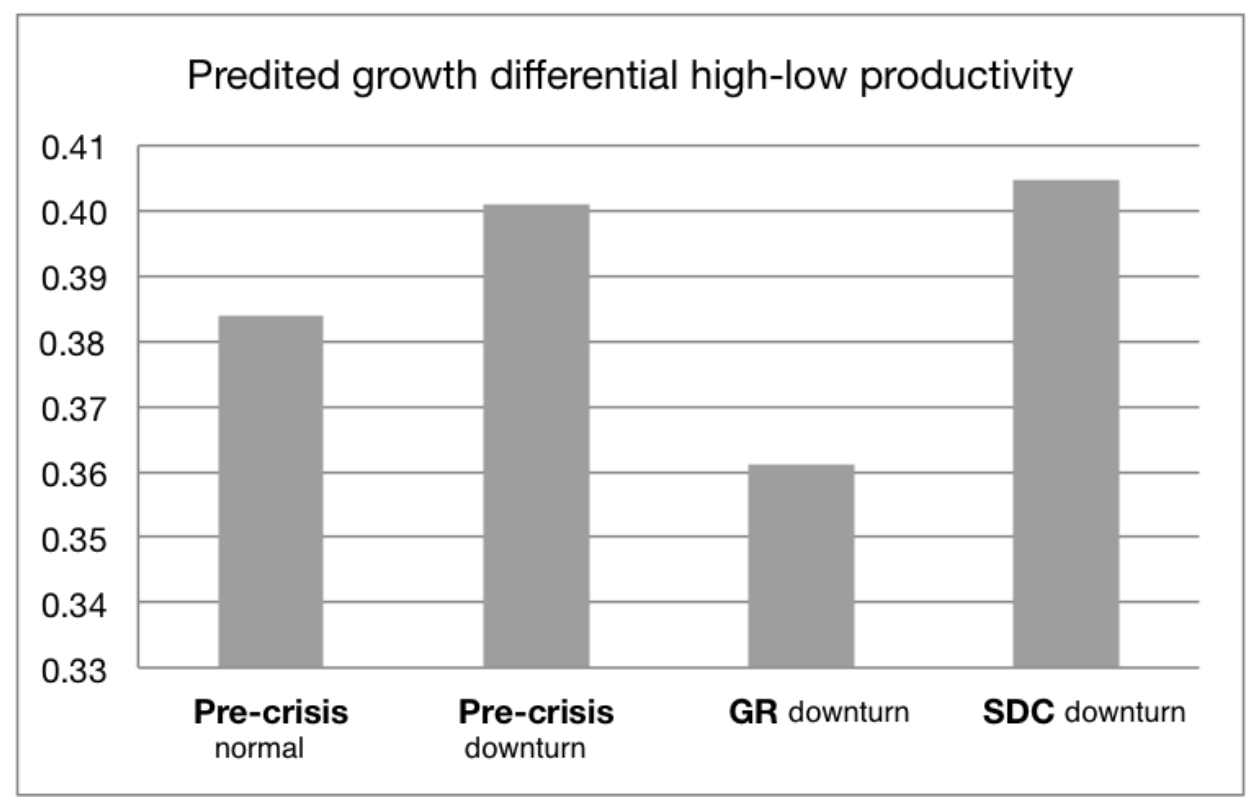




\subsection{Changing patterns of PER over the GR: the Role of Trade Collapse and Credit Crunch}

The reduction countercyclical PER during the Great Recession has also been found for the US (Foster, Grim, and Haltiwanger 2016). Indeed, our results show that PER was muted during the Great Recession, while it reacquired its cleansing role during the Sovereign Debt Crisis. Two events stand out that could provide an explanation for the difference between normal downturns, the GR and the SDC and provide an explanation for the commonality of the finding across US and EU. First, the onset of the crisis coincided with a sharp downturn in global trade. Next, the crisis was a period with tight credit conditions which was prolonged in the EU but less so in the US. Both phenomena are discussed in turn.

\subsubsection{Trade Collapse}

The literature has emphasized the positive relationship between exporting status and productivity (Melitz 2003, Melitz and Ottaviano 2008). It is plausible that the reduced PER over the GR results from large and productive firms not managing to expand during the collapse of international trade. If productive firms failed to attract the resources they needed to expand, then it should show up in reduced PER. In table 10 we explore whether the lack of silver lining was particularly important in sectors more exposed to trade. After splitting the sample into pre-crisis, GR and SDC, we use a triple interaction between initial productivity, cycle and a sector-specific indicator of the exposure to the trade collapse. This is done with the help of an indicator of sector exposure to trade that is computed from the input-output tables TIVA of the OECD (details are shown in the Appendix table A5). This exposure is taken as an average of the few available years and is country-specific. We then multiply that with the actual change in aggregate exports, in each country. We construct a dummy (labelled "d_exp" in the table) that takes the value 1 if the country-sector was more affected by the trade collapse than the country' median in the time period considered and 0 otherwise. The purpose is to explore if it was particularly in country-sectors more exposed to the trade collapse where PER declined. Table 10 shows that indeed, unlike in the pre-crisis period and over the SDC, during the GR (column 2), country-sectors more affected by the trade collapse featured muted employment PER.

Figure 3 shows the employment growth difference between high and low productive firms, splitting the country-sectors into those with high and low exposure to the trade collapse. We show the PER during a bust in the pre-crisis period (bars 1 and 2), during the GR (bars 3 and 4) and the SDC (bars 5 and 6). The first bar of each group represents PER during downturns for country-sectors less exposed to the trade collapse. The second bar of each group represents PER in downturns for country-sectors more exposed to international trade. The message is clear: in those country-sectors more exposed to the trade collapse, the GR was a period of muted cleansing relative to other busts. However, during the Sovereign Debt crisis, the normal cyclical pattern returned in place.

Table 11 studies the impact of the trade collapse on capital reallocation. Consistent with the findings in Table 9. PER over the cycle appears to be relevant only during the SDC. The positive coefficient on the triple interaction in column 3 suggests that the firms more exposed to trade drive the result. While adjustment costs make capital reallocation relatively inelastic over the cycle, the abrupt collapse of global trade taking place during the GR manifested itself mostly during the subsequent period, when unproductive firms more exposed to trade were forced out of the market. 
Table 10: PER, Cycle and Exports; Employment. Only relevant interactions are reported

\begin{tabular}{|c|c|c|c|}
\hline VARIABLES & $\begin{array}{c}(1) \\
\text { Pre-crisis }\end{array}$ & $\begin{array}{l}(2) \\
\text { GR }\end{array}$ & $\begin{array}{c}(3) \\
\text { SDC }\end{array}$ \\
\hline$\Delta$ cycle & $\begin{array}{c}0.216^{* * *} \\
(0.0689)\end{array}$ & & $\begin{array}{c}-0.0501 \\
(0.0501)\end{array}$ \\
\hline Rel. $\operatorname{prod}_{-3}$ & $\begin{array}{l}1.057^{* * *} \\
(0.0827)\end{array}$ & $\begin{array}{c}1.019^{* * *} \\
(0.123)\end{array}$ & $\begin{array}{c}0.928^{* * *} \\
(0.0907)\end{array}$ \\
\hline Rel. prod $_{-3} \times \Delta$ cycle & $\begin{array}{l}-0.287 \\
(0.523)\end{array}$ & $\begin{array}{c}-2.730^{* * *} \\
(0.864)\end{array}$ & $\begin{array}{c}-0.320^{* * *} \\
(0.0855)\end{array}$ \\
\hline Rel. $\operatorname{prod}_{-3} \times \Delta$ cycle $\times \mathrm{d}_{\exp }$ & $\begin{array}{l}-0.111 \\
(0.573)\end{array}$ & $\begin{array}{c}4.334^{* * *} \\
(1.011)\end{array}$ & $\begin{array}{c}-0.933 \\
(1.492)\end{array}$ \\
\hline Observations & 4,526 & 935 & 1,668 \\
\hline Adjusted R-squared & 0.489 & 0.414 & 0.540 \\
\hline Controls & YES & YES & YES \\
\hline
\end{tabular}

Table 11: PER, Cycle and Exports; Capital. Only relevant interactions are reported

\begin{tabular}{lccc}
\hline VARIABLES & $(1)$ & $(2)$ & $(3)$ \\
& Pre-crisis & GR & SDC \\
\hline cycle & & & \\
& $0.320^{* * *}$ & & $0.207^{* *}$ \\
Rel. prod $_{-3}$ & $(0.0975)$ & & $(0.0831)$ \\
& $0.749^{* * *}$ & $0.776^{* * *}$ & $0.724^{* * *}$ \\
Rel. $\operatorname{prod}_{-3} \times \Delta$ cycle & $(0.0589)$ & $(0.185)$ & $(0.0716)$ \\
& -0.266 & -1.303 & $-0.492^{* *}$ \\
Rel. $\operatorname{prod}_{-3} \times \Delta$ cycle $\times \mathrm{d}_{\text {exp }}$ & $(0.361)$ & $(1.390)$ & $(0.209)$ \\
& 0.204 & 2.016 & $-2.177^{*}$ \\
& $(0.464)$ & $(1.576)$ & $(1.293)$ \\
Observations & & & \\
Adjusted R-squared & 4,526 & 935 & 1,668 \\
Controls & 0.463 & 0.379 & 0.472 \\
& YES & YES & YES \\
\hline
\end{tabular}

Robust standard errors in parentheses *** $\mathrm{p}<0.01,{ }^{* *} \mathrm{p}<0.05,{ }^{*} \mathrm{p}<0.1$ 
Figure 3: PER, Cycle and Exports (Employment)

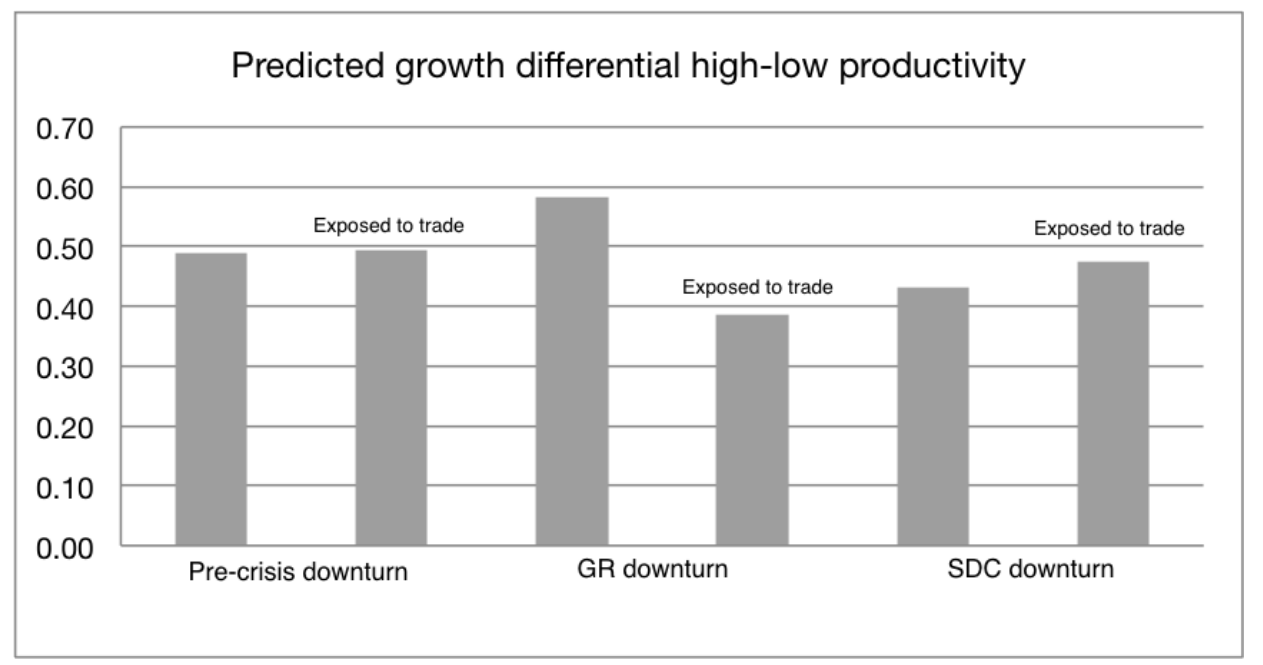

\subsubsection{Credit Crunch}

Next, we consider the credit crisis, another standout feature of the GR in both Europe and the US, although the financial crisis endured with the ensuing SDC in Europe. Theory is less clear about the impact of credit frictions on PER. Mostly, we would expect tightness of credit to prevent firms, particularly those most dependent on bank credit, to grow when fundamental conditions were favorable. If credit constraints showed up in a manner unrelated (or positively related) to productivity, then productive firms might be prevented from growing, thus reducing PER. Another path may be that potentially productive entrants, especially those that invest in intangible and thus non-collateralizable assets, may be prevented from entering the markets. Unfortunately, owing to lack of data on entrants, we are not able to explore this directly. These theoretical paths seem to be less relevant during the GR, where any cleansing would like occur through reductions in size of unproductive firms rather than increases at productivive firms. However, as global economic conditions improved, the sovereign debt crisis created continued problems in credit markets in a subset of EU countries.

We explore the role of credit constraints for employment and capital reallocation. As before, we run the baseline for the pre-crisis and two crisis periods, interacting initial relative productivity, the cycle, and a firm-specific dummy that takes the value 1 if the (representative) firm is more dependent on bank credit -and therefore more exposed to the credit crisis- than the rest of firms operating in the same country/sector/year 10

As a proxy for bank-dependency we exploit two sources of information available from CompNet. The first is the amount of collateral, defined as the share of fixed tangible assets, and the second is the equity-ratio, defined as the ratio of equity over total assets. We construct a dummy taking the value 1 if the firm has an equity ratio or collateral below the median in each country/sector/year. That is, we flag firms with a larger dependence on bank credit relative to other firms in their same country, sector. and year

Table 12 looks at employment reallocation and shows in columns 1-3 the results for firms with less collateral and in columns 4-6 the results for firms with a lower equity ratio. During

\footnotetext{
${ }^{10}$ This identification strategy has been followed in other papers like for example Coricelli and Frigerio (2015), where it is argued that the adverse effects of credit constraints are softened in sectors that rely more on alternative sources of financing such as trade credit, or with more favorable access to credit because of higher collateral.
} 
the pre-crisis we find that employment PER was enhanced during downturns, but less so for firms with low collateral. This could reflect the fact productive firms with no collateral were not granted the required credit to expand during this period therefore decreasing the PER of these type of firms. Over the GR, however, the relation changes. Downturns lose their cleansing property independently on bank-dependency. Hence employment is not reallocated towards more productive firms, with or without collateral. Turning to columns 4-6, we find that in the pre-crisis period downturns enhanced PER, both for firms with above and below median equity ratio. However, in the GR firms cleansing was significantly more muted amongst firms with less equity, that is, more dependent on bank credit. The result suggests that during the GR productive firms were not able to attract the resources needed if they were more exposed to banks. During the SDC, the normal cleansing pattern for employment returns.

Table 13 looks at capital reallocation. Consistent with the findings in Table 9, we do not find any significant PER over the cycle in the pre crisis period. Somehow surprisingly, we find no role for collateral in explaining different patterns of cyclical reallocation of capital in any of the different sub-periods considered. With the indicator of bank dependency based on the equityratio, we find that in the pre-crisis period PER is stronger for firms that are more dependent on banks. The relation is reversed during the GR, where cleansing was muted particularly among credit-dependent firms, suggesting that highly productive firms that were more dependent on banks could not grow due to unavailability of funds dictated by the credit crunch. As in Table 9 , we find significant PER over the SDC. The fact that no PER over the cycle can be detected, even allowing for differences among firms in bank exposure, suggests that indeed pervasive credit constraints over the SDC might have enhanced the productivity enhancing role of downturns by forcing unproductive firms out of the market.

Table 12: PER, Cycle and Credit; Employment. Only relevant interactions are reported

\begin{tabular}{|c|c|c|c|c|c|c|}
\hline VARIABLES & $\begin{array}{c}(1) \\
\text { Pre-crisis }\end{array}$ & $\begin{array}{l}(2) \\
\text { GR }\end{array}$ & $\begin{array}{c}(3) \\
\text { SDC }\end{array}$ & $\begin{array}{c}(4) \\
\text { Pre-crisis }\end{array}$ & $\begin{array}{l}5) \\
\text { GR }\end{array}$ & $\begin{array}{c}6) \\
\text { SDC }\end{array}$ \\
\hline$\Delta$ cycle & $\begin{array}{c}0.309^{* * *} \\
(0.0583)\end{array}$ & & $\begin{array}{l}-0.103 \\
(0.0673)\end{array}$ & $\begin{array}{c}0.233^{* * *} \\
(0.0769)\end{array}$ & & $\begin{array}{r}-0.167^{* *} \\
(0.0686)\end{array}$ \\
\hline Rel. $\operatorname{prod}_{-3}$ & $\begin{array}{c}0.883^{* * *} \\
(0.124)\end{array}$ & $\begin{array}{c}1.088^{* * *} \\
(0.135)\end{array}$ & $\begin{array}{c}1.008^{* * *} \\
(0.0951)\end{array}$ & $\begin{array}{c}0.717^{* * *} \\
(0.110)\end{array}$ & $\begin{array}{c}0.831^{* * *} \\
(0.135)\end{array}$ & $\begin{array}{c}0.942^{* * *} \\
(0.0941)\end{array}$ \\
\hline Rel. prod $_{-3} \times \Delta$ cycle & $\begin{array}{c}-0.784^{* *} \\
(0.315)\end{array}$ & $\begin{array}{l}1.170^{*} \\
(0.592)\end{array}$ & $\begin{array}{l}-0.123 \\
(0.140)\end{array}$ & $\begin{array}{c}-0.494^{*} \\
(0.283)\end{array}$ & $\begin{array}{c}0.879 \\
(0.525)\end{array}$ & $\begin{array}{l}-0.178^{*} \\
(0.0995)\end{array}$ \\
\hline Rel. $\operatorname{prod}_{-3} \times \Delta$ cycle $\times \mathrm{d}_{\text {collat }}$ & $\begin{array}{l}0.406^{*} \\
(0.234)\end{array}$ & $\begin{array}{c}0.608 \\
(0.590)\end{array}$ & $\begin{array}{l}-0.360 \\
(0.258)\end{array}$ & & & \\
\hline Rel. prod $_{-3} \times \Delta$ cycle $\times \mathrm{d}_{\text {equity }}$ & & & & $\begin{array}{l}-0.238 \\
(0.760)\end{array}$ & $\begin{array}{l}1.275^{*} \\
(0.721)\end{array}$ & $\begin{array}{l}-0.147 \\
(0.228)\end{array}$ \\
\hline Observations & 4,390 & 912 & 1,622 & 3,448 & 718 & 1,604 \\
\hline Adjusted R-squared & 0.476 & 0.414 & 0.547 & 0.459 & 0.406 & 0.543 \\
\hline Controls & YES & YES & YES & YES & YES & YES \\
\hline
\end{tabular}

In sum, we find some evidence that productivity enhacing reallocation of labor was muted owing to both the trade collapse and the credit crunch during the GR. The productivityenhancing effects of capital reallocation are less affected by typical cycles than labor is, probably due to the presence of important adjustment costs making it "quasi-fixed". However, the cyclical 
Table 13: PER, Cycle and Credit; Capital. Only relevant interactions are reported

\begin{tabular}{|c|c|c|c|c|c|c|}
\hline VARIABLES & $\begin{array}{c}(1) \\
\text { Pre-crisis }\end{array}$ & $\begin{array}{l}(2) \\
\text { GR }\end{array}$ & $\begin{array}{c}(3) \\
\text { SDC }\end{array}$ & $\begin{array}{c}(4) \\
\text { Pre-crisis }\end{array}$ & $\begin{array}{l}(5) \\
\text { GR }\end{array}$ & $\begin{array}{c}(6) \\
\text { SDC }\end{array}$ \\
\hline$\Delta$ cycle & $\begin{array}{c}0.325^{* * *} \\
(0.0864)\end{array}$ & & $\begin{array}{c}0.233^{* * *} \\
(0.0679)\end{array}$ & $\begin{array}{c}0.282^{* *} \\
(0.114)\end{array}$ & & $\begin{array}{c}0.0396 \\
(0.0558)\end{array}$ \\
\hline Rel. $\operatorname{prod}_{-3}$ & $\begin{array}{c}0.638^{* * *} \\
(0.0709)\end{array}$ & $\begin{array}{c}0.832^{* * *} \\
(0.110)\end{array}$ & $\begin{array}{c}0.737^{* * *} \\
(0.0740)\end{array}$ & $\begin{array}{c}0.574^{* * *} \\
(0.0760)\end{array}$ & $\begin{array}{c}0.729 * * * \\
(0.154)\end{array}$ & $\begin{array}{c}0.778^{* * *} \\
(0.0751)\end{array}$ \\
\hline Rel. prod $_{-3} \times \Delta$ cycle & $\begin{array}{l}-0.301 \\
(0.235)\end{array}$ & $\begin{array}{c}0.390 \\
(0.754)\end{array}$ & $\begin{array}{c}-0.504^{* * *} \\
(0.0917)\end{array}$ & $\begin{array}{c}0.258 \\
(0.289)\end{array}$ & $\begin{array}{l}-0.285 \\
(0.609)\end{array}$ & $\begin{array}{c}-0.389^{* * *} \\
(0.0999)\end{array}$ \\
\hline Rel. prod $_{-3} \times \Delta$ cycle $\times \mathrm{d}_{\text {collat }}$ & $\begin{array}{c}0.200 \\
(0.201)\end{array}$ & $\begin{array}{c}0.591 \\
(0.525)\end{array}$ & $\begin{array}{c}0.0950 \\
(0.344)\end{array}$ & & & \\
\hline Rel. $\operatorname{prod}_{-3} \times \Delta$ cycle $\times \mathrm{d}_{\text {equity }}$ & & & & $\begin{array}{c}-0.759^{*} \\
(0.438)\end{array}$ & $\begin{array}{c}2.026^{* * *} \\
(0.604)\end{array}$ & $\begin{array}{c}0.470 \\
(0.291)\end{array}$ \\
\hline Observations & 4,390 & 912 & 1,622 & 3,448 & 718 & 1,604 \\
\hline Adjusted R-squared & 0.460 & 0.388 & 0.479 & 0.465 & 0.385 & 0.484 \\
\hline Controls & YES & YES & YES & YES & YES & YES \\
\hline
\end{tabular}

response of PER of capital is significantly in the last part of the sample during the SDC.

\section{Conclusions}

Based on evidence from a growing literature, factor reallocation is an important contributor to aggregate productivity and output growth. So far, relatively little evidence has been available for European countries, and less in a manner that allows cross-country comparisons. In this paper, we make use of a unique dataset collected using the distributed micro data approach, with harmonized data preparation and collection of indicators and moments using identical methodology in each country. The analysis has followed Foster, Grim, and Haltiwanger (2016) to estimate the elasticity of firm growth with respect to initial relative TFP as a measure of productivity enhancing reallocation.

The paper has shown differences in the pattern of productivity enhancing reallocation across countries and tied these to differences in structural policy. Next, the paper has assessed how PER changes over the cycle, and in particular during the Great Recession and the ensuing sovereign debt crisis. We find that all countries exhibit productivity enhancing reallocation but that its strength varies across countries. Part of the difference can be attributed to differences in the firm size distribution, but it partly reflects differences in regulatory environment. In particular stringent product market regulation and labor market regulation reduce PER.

Interestingly, we find that the patterns of productivity enhancing regulation have changed over the recent events. In general, we find that PER is procyclical. In other words, in a downturn low productive firms shrink more. However, over the great recession, this pattern broke down. Part of this may be attributed to the sharp drop in exports, which harmed the more productive and larger exporting firms and required them to shed labor proportionately more than less productive non-exporting firms. Another contributor to the reduction in PER over the great recession is the role of credit constraints. These are seen to have hampered the relative growth of firms more dependent on bank credit to grow in the crisis. 
The paper has also uncovered some interesting differences in the patterns of reallocation of labor versus capital. First, capital reallocation is less sensitive to the cycle than employment reallocation, probably due to the fact that the cycle is by definition a transitory phenomenon, but capital is costly to adjust. Second, we find that the trade collapse has not changed the cyclical pattern of PER for capital during the GR. In line with the previous more general result, it is likely that sunk production capital is high for exporters and that the trade collapse was anticipated as temporary, which could help explain the differential pattern between capital and labor over the GR.

This paper is an initial exploration using the CompNet data that are available for crosscountry analysis. The breadth of indicators collected and the level of (sub-)industry detail will allow many different types of analyses on a host of issues related to productivity, finance, trade and employment. As an extension to the current paper, we first will analyze different measures of PER, for example resource growth related to wedges between factor marginal products and factor costs rather than to relative productivity. Further, many more countries are available in the CompNet data, but sample characteristics vary. An extension of our analysis could compare and contrast results based on the selection of firms and countries in the datasets. Finally, our analysis has pointed to the importance of expectations of firms about future conditions when making factor input decisions. The CompNet data, in conjunction with detailed trade data and macro-level data could aid in understanding the role of confidence and expectation formation in growth. 


\section{References}

Andrews, Dan, and Federico Cingano. 2014. "Public policy and resource allocation: evidence from firms in Oecd countries." Economic Policy, 29(78): 253-296.

Ayyagari, Meghana, Asli Demirgüç-Kunt, and Vojislav Maksimovic. 2011. "Small vs. young firms across the world: contribution to employment, job creation, and growth." World Bank Policy Research Working Paper 5631.

Bartelsman, Eric J., Eva Hagsten, and Michael Polder. 2018. "Micro moments database for cross-country analysis of ICT, innovation, and economic outcomes." Journal of Economics and Management Strategy.

Bartelsman, Eric J., John C. Haltiwanger, and Stefano Scarpetta. 2013. "Cross-Country Differences in Productivity: The Role of Allocation and Selection." American Economic Review, 103(1): 305-334.

Bartelsman, Eric J., Pieter A. Gautier, and Joris De Wind. 2016. "Employment Protection, Technology Choice, and Worker Allocation." International Economic Review, 57(3): 787826.

Bartelsman, Eric J., Ricardo J. Caballero, and Richard K. Lyons. 1994. "Consumer and Supplier Driven Externalities." American Economic Review, 84(4): 1075-84.

Bartelsman, Eric J., Stefano Scarpetta, and Fabiano Schivardi. 2005. "Comparative analysis of firm demographics and survival: evidence from micro-level sources in OECD countries." Industrial and Corporate Change, 14(3): 365-391.

Bassanini, Andrea, Luca Nunziata, and Danielle Venn. 2009. "Job protection legislation and productivity growth in OECD countries." Economic Policy, 24(58): 349-402.

Bernanke, B.S., Mark Gertler, and Simon Gilchrist. 1999a. "The financial accelerator in a quantitative business cycle framework." In Handbook of Macroeconomics.

Bernanke, B.S., Mark Gertler, and Simon Gilchrist. 1999b. "The financial accelerator in a quantitative business cycle framework."

Bertola, G., and R. Rogerson. 1997. "Institutions and labor reallocation." European Economic Review, 41(6): 1147-1171.

Boeri, Tito, and Herbert Bruecker. 2011. "Short-time work benefits revisited: some lessons from the Great Recession." Economic Policy, 26(68): 697-765.

Buera, Francisco J., and Benjamin Moll. 2015. "Aggregate Implications of a Credit Crunch: The Importance of Heterogeneity." American Economic Journal: Macroeconomics, 7(3): 1-42.

Caballero, Ricardo J., and Mohamad L. Hammour. 1994. "The Cleansing Effect of Recessions." The American Economic Review, 84(5): 1350-1368.

Cooley, Thomas F., and Vincenzo Quadrini. 2001. "Financial Markets and Firm Dynamics." The American Economic Review, 91(5): 1286-1310.

Cooper, Russell W., and John C. Haltiwanger. 2006. "On the Nature of Capital Adjustment Costs." The Review of Economic Studies, 73(3): 611-633. 
Coricelli, Fabrizio, and Marco Frigerio. 2016. "Inter-Enterprise Credit and Adjustment During Financial Crises: The Role of Firm Size." CEPR Discussion Paper 11680.

Criscuolo, Chiara, Peter Gal, and Carlo Menon. 2014. "The Dynamics of Employment Growth." OECD Science, Technology and Industry Policy Papers 14.

Davis, Steven J., and John Haltiwanger. 1992. "Gross Job Creation, Gross Job Destruction, and Employment Reallocation." The Quarterly Journal of Economics, 107(3): 819-863.

Decker, Ryan, John Haltiwanger, Ron Jarmin, and Javier Miranda. 2014. "The Role of Entrepreneurship in US Job Creation and Economic Dynamism." The Journal of Economic Perspectives, 28(3): 3-24.

Eisfeldt, Andrea L., and Adriano A. Rampini. 2006. "Capital reallocation and liquidity." Journal of Monetary Economics, 53(3): 369-399.

Fernandez, Cristina, Roberto Garcia, Paloma Lopez Garcia, Benedicta Marzinotto, Roberta Serafina, Juuso Vanhala, and Ladislav Wintr. 2016. "Firm growth in Europe: An overview based on the CompNet labour module." ECB Working Paper Series 2048.

Foster, Lucia, Cheryl Grim, and John Haltiwanger. 2016. "Reallocation in the Great Recession: Cleansing or Not?" Journal of Labor Economics, 34(S1): S293-S331.

Gilchrist, Simon, Jae W. Sim, and Egon Zakrajek. 2013. "Misallocation and financial market frictions: Some direct evidence from the dispersion in borrowing costs." Review of Economic Dynamics, 16(1): 159-176.

Gopinath, Gita, Şebnem Kalemli-Özcan, Loukas Karabarbounis, and Carolina Villegas-Sanchez. 2017. "Capital Allocation and Productivity in South Europe." The Quarterly Journal of Economics, 132(4): 1915-1967.

Hagedorn, Marcus, and Iourii Manovskii. 2008. "The Cyclical Behavior of Equilibrium Unemployment and Vacancies Revisited." American Economic Review, 98(4): 1692-1706.

Hopenhayn, Hugo A. 1992. "Entry, Exit, and firm Dynamics in Long Run Equilibrium." Econometrica, 60(5): 1127-1150.

Hsieh, Chang-Tai, and Peter J. Klenow. 2009. "Misallocation and Manufacturing TFP in China and India." The Quarterly Journal of Economics, 124(4): 1403-1448.

Hyatt, Henry R., and James R. Spletzer. 2013. "The recent decline in employment dynamics." IZA Journal of Labor Economics, 2(1): 1-21.

Jovanovic, Boyan. 1982. "Selection and the Evolution of Industry." Econometrica, 50(3): 649670.

Krusell, Per, Toshihiko Mukoyama, Richard Rogerson, and Ayşegül Şahin. 2017. "Gross Worker Flows over the Business Cycle." American Economic Review, 107(11): 3447-3476.

Lopez-Garcia, Paloma, and Filippo di Mauro. 2015. "Assessing European competitiveness: the new CompNet micro-based database." ECB Working Paper Series 1764.

Lucas, Robert E. 1978. "Size Distribution of Business Firms." Bell Journal of Economics, $9(2): 508-523$. 
Lucas, Robert E. 1988. "On the mechanics of economic development." Journal of Monetary Economics, 22(1): 3-42.

Melitz, Marc J. 2003. "The Impact of Trade on Intra-Industry Reallocations and Aggregate Industry Productivity." Econometrica, 71(6): 1695-1725.

Melitz, Marc J., and Gianmarco I. P. Ottaviano. 2008. "Market Size, Trade, and Productivity." The Review of Economic Studies, 75(1): 295-316.

Midrigan, Virgiliu, and Daniel Yi Xu. 2014. "Finance and Misallocation: Evidence from PlantLevel Data." American Economic Review, 104(2): 422-458.

Mortensen, Dale T., and Christopher Pissarides. 1994. "Job Creation and Job Destruction in the Theory of Unemployment." Review of Economic Studies, 61(3(208)): 397-416.

Poschke, Markus. 2009. "Employment protection, firm selection, and growth." Journal of Monetary Economics, 56(8): 1074-1085.

Restuccia, Diego, and Richard Rogerson. 2008. "Policy distortions and aggregate productivity with heterogeneous establishments." Review of Economic Dynamics, 11(4): 707-720.

Shea, John. 1993. "Do Supply Curves Slope Up?" The Quarterly Journal of Economics, 108(1): 1-32.

Wooldridge, Jeffrey M. 2009. "On estimating firm-level production functions using proxy variables to control for unobservables." Economics Letters, 104(3): 112-114. 


\section{A APPENDIX}

Table A1: Comparison $\Delta \mathrm{L}$ and Actual Employment Growth

\begin{tabular}{lcc}
\hline VARIABLES & $(1)$ & $(2)$ \\
$\Delta$ cycle & $\begin{array}{c}0.150^{* * *} \\
(0.0291)\end{array}$ & $\begin{array}{c}0.122^{* * *} \\
(0.0309)\end{array}$ \\
Rel. prod Actual $_{-3}$ & $\begin{array}{c}0.788^{* * *} \\
(0.101)\end{array}$ & $\begin{array}{c}0.492^{* * *} \\
(0.0706)\end{array}$ \\
& & \\
Observations & 3,984 & 3,984 \\
R-squared & 0.497 & 0.498 \\
Controls & YES & YES \\
\hline \multicolumn{2}{l}{ Robust standard errors in parentheses } \\
$* * *$ & $\mathrm{p}<0.01, * * \mathrm{p}<0.05, * \mathrm{p}<0.1$
\end{tabular}

Figure A1: Heat Map of Estimated vs Actual Growth Rates of Employment
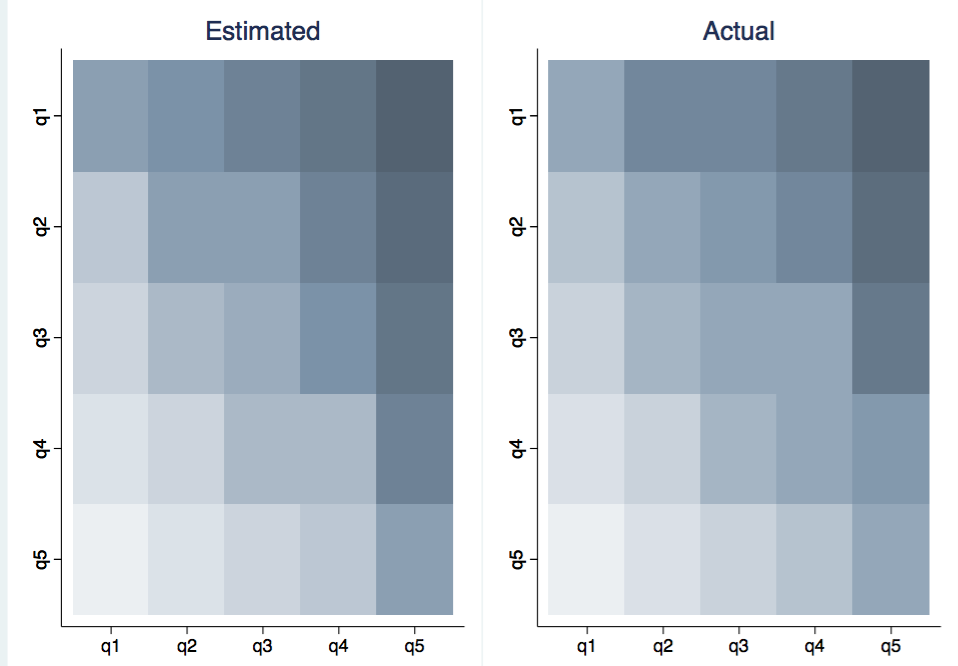
Table A2: Sectors in CompNet data

\begin{tabular}{|c|c|c|c|}
\hline Sector & Description & 2-digit & Description \\
\hline \multirow{23}{*}{$\mathrm{C}$} & \multirow{23}{*}{ Manufacturing } & 10 & Manufacture of food products \\
\hline & & 11 & Manufacture of beverages \\
\hline & & 12 & Manufacture of tobacco products \\
\hline & & 13 & Manufacture of textiles \\
\hline & & 14 & Manufacture of wearing apparel \\
\hline & & 15 & Manufacture of leather and related products \\
\hline & & 16 & Manufacture of wood and of products of wood and cork, except furniture \\
\hline & & 17 & Manufacture of paper and paper products \\
\hline & & 18 & Printing and reproduction of recorded media \\
\hline & & 20 & Manufacture of chemicals and chemical products \\
\hline & & 21 & Manufacture of basic pharmaceutical products and pharmaceutical preparations \\
\hline & & 22 & Manufacture of rubber and plastic products \\
\hline & & 23 & Manufacture of other nonmetallic mineral products \\
\hline & & 24 & Manufacture of basic metals \\
\hline & & 25 & Manufacture of fabricated metal products, except machinery and equipment \\
\hline & & 26 & Manufacture of computer, electronic and optical products \\
\hline & & 27 & Manufacture of electrical equipment \\
\hline & & 28 & Manufacture of machinery and equipment $\mathrm{n}$ \\
\hline & & 29 & Manufacture of motor vehicles, trailers and semitrailers \\
\hline & & 30 & Manufacture of other transport equipment \\
\hline & & 31 & Manufacture of furniture \\
\hline & & 32 & Other manufacturing \\
\hline & & 33 & Repair and installation of machinery and equipment \\
\hline \multirow{3}{*}{$\mathrm{F}$} & \multirow{3}{*}{ Construction } & 41 & Construction of buildings \\
\hline & & 42 & Civil engineering \\
\hline & & 43 & Specialised construction activities \\
\hline \multirow{3}{*}{ G } & \multirow{3}{*}{ Wholesale and retail trade } & 45 & Wholesale and retail trade and repair of motor vehicles and motorcycles \\
\hline & & 46 & Wholesale trade, except of motor vehicles and motorcycles \\
\hline & & 47 & Retail trade, except of motor vehicles and motorcycles \\
\hline \multirow{5}{*}{$\mathrm{H}$} & \multirow{5}{*}{ Transportation } & 49 & Land transport and transport via pipelines \\
\hline & & 50 & Water transport \\
\hline & & 51 & Air transport \\
\hline & & 52 & Warehousing and support activities for transportation \\
\hline & & 53 & Postal and courier activities \\
\hline \multirow[t]{2}{*}{ I } & \multirow[t]{2}{*}{ Hotels and Restaurants } & 55 & Accommodation \\
\hline & & 56 & Food and beverage service activities \\
\hline \multirow{6}{*}{$\mathrm{J}$} & \multirow{6}{*}{ Information and Communication } & 58 & Publishing activities \\
\hline & & 59 & Motion picture, video and television programme production, sound recording and music publishing \\
\hline & & 60 & Programming and broadcasting activities \\
\hline & & 61 & Telecommunications \\
\hline & & 62 & Computer programming, consultancy and related activities \\
\hline & & 63 & Information service activities \\
\hline \multirow{6}{*}{ M } & \multirow{6}{*}{ Professional Services } & 70 & Activities of head offices; management consultancy activities \\
\hline & & 71 & Architectural and engineering activities; technical testing and analysis \\
\hline & & 72 & Scientific research and development \\
\hline & & 73 & Advertising and market research \\
\hline & & 74 & Other professional, scientific and technical activities \\
\hline & & 75 & Veterinary activities \\
\hline \multirow{6}{*}{$\mathrm{N}$} & \multirow{6}{*}{ Business Services } & 77 & Rental and leasing activities \\
\hline & & 78 & Employment activities \\
\hline & & 79 & Travel agency, tour operator and other reservation service and related activities \\
\hline & & 80 & Security and investigation activities \\
\hline & & 81 & Services to buildings and landscape activities \\
\hline & & 82 & Office administrative, office support and other business support activities \\
\hline
\end{tabular}

Table A3: Average Capital growth (pct) in transition matrix cells*

\begin{tabular}{rrrrrr}
\hline & $\mathrm{Q}_{t}$ & $\mathrm{Q} 2_{t}$ & $\mathrm{Q} 3_{t}$ & $\mathrm{Q} 4_{t}$ & $\mathrm{Q} 5_{t}$ \\
\hline $\mathrm{Q} 1_{t-3}$ & 2 & 12 & 22 & 41 & 86 \\
$\mathrm{Q} 2_{t-3}$ & -9 & 3 & 9 & 29 & 68 \\
$\mathrm{Q} 3_{t-3}$ & -21 & -8 & 0 & 13 & 64 \\
$\mathrm{Q} 4_{t-3}$ & -33 & -23 & -11 & -3 & 39 \\
$\mathrm{Q} 5_{t-3}$ & -42 & -40 & -31 & -19 & -3 \\
\hline
\end{tabular}

${ }^{*} \mathrm{Q} 1$ is the quintile of smallest firms, Q5 the largest. 


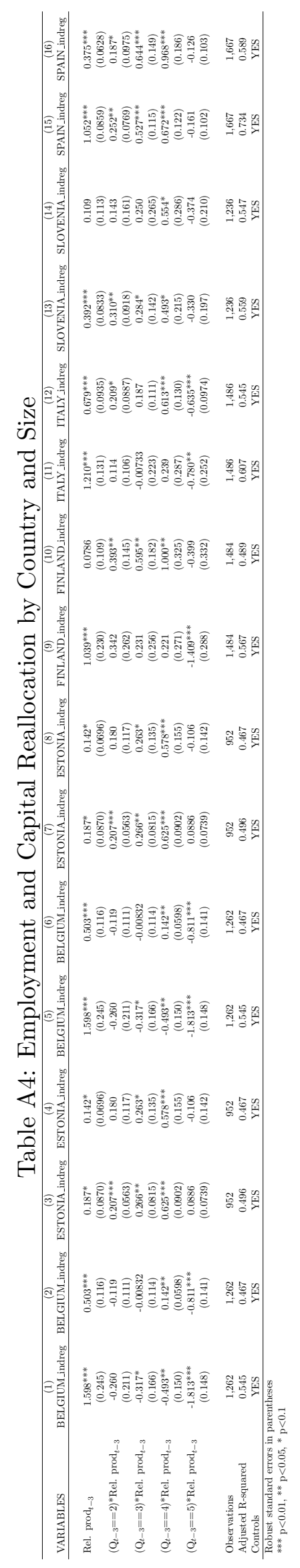


Table A5: Sector-exposure to exports, country detail (average 2005, 2008 and 2009)

\begin{tabular}{lcccccccc}
\hline country & Manufacturing & Construction & $\begin{array}{l}\text { Wholesale and } \\
\text { retail trade }\end{array}$ & $\begin{array}{l}\text { Transportation } \\
\text { and storage }\end{array}$ & $\begin{array}{l}\text { Accommodation } \\
\text { and restaurants }\end{array}$ & $\begin{array}{c}\text { ICT } \\
\text { Professional } \\
\text { services }\end{array}$ & $\begin{array}{l}\text { Administrative } \\
\text { services }\end{array}$ \\
\hline BELGIUM & 54.06 & 6.97 & 23.07 & 39.95 & 23.07 & 39.95 & 19.91 \\
ESTONIA & 53.24 & 8.01 & 21.23 & 59.10 & 21.23 & 59.10 & 22.93 \\
FINLAND & 37.21 & 2.04 & 11.50 & 39.80 & 11.50 & 39.80 & 17.28 \\
ITALY & 29.23 & 2.69 & 10.33 & 19.05 & 10.33 & 19.05 & 10.50 \\
SLOVENIA & 51.94 & 7.26 & 17.16 & 59.19 & 17.16 & 59.19 & 15.05 \\
SPAIN & 26.36 & 1.32 & 6.32 & 34.61 & 6.32 & 34.61 & 11.97 \\
\hline
\end{tabular}

Note: Sector exposure measured as the share of sector value added exported

Source: Own calculations on TIVA (OECD) 